\title{
Bone Remodeling and the Microbiome
}

\author{
Roberto Pacifici \\ Division of Endocrinology, Metabolism and Lipids, Department of Medicine, and Immunology and Molecular \\ Pathogenesis Program, Emory University, Atlanta, Georgia 30322 \\ Correspondence: roberto.pacifici@emory.edu
}

Exposed surfaces of mammals are colonized with 100 trillion indigenous bacteria, fungi, and viruses, creating a diverse ecosystem known as the microbiome. The gastrointestinal tract harbors the greatest numbers of these microorganisms, which regulate human nutrition, metabolism, and immune system function. Moreover, the intestinal microbiota contains pro- and anti-inflammatory products that modulate immune responses and may play a role in maintaining gut barrier function. Therefore, the community composition of the microbiota has profound effects on the immune status of the host and impacts the development and/or progression of inflammatory diseases. Accordingly, numerous studies have shown differences in the microbiota of patients with and without a given inflammatory condition. There is now strong evidence that the gut microbiome regulates bone homeostasis in health and disease, and that prebiotic and probiotics protect against bone loss. Herein, the evidence supporting the role of the microbiota and the effects of prebiotic and probiotics will be reviewed.

Exposed surfaces of mammals are colonized Ewith 100 trillion indigenous bacteria, fungi, and viruses, creating a diverse ecosystem known as the microbiota (Tremaroli and Backhed 2012; Sommer and Backhed 2013). The microbiome consists of the genes these cells harbor (Turnbaugh et al. 2007). The gastrointestinal tract harbors the greatest numbers of these microorganisms, which regulate human nutrition, metabolism, and immune system function. The gut microbiota holds ten times more bacterial cells than human cells in the body, and possess five million genes. Moreover, the intestinal microbiota contains pro- and anti-inflammatory products that modulate immune responses (Surana and Kasper 2014) and may play a role in maintaining gut barrier function. Therefore, the community composition of the microbiota has profound effects on the immune status of the host and impacts the development and/or progression of inflammatory diseases. Microbial colonization of the gastrointestinal tract starts at birth and leads to the establishment of a diverse community by early adulthood (Eckburg et al. 2005). Gut luminal bacteria beneficially influence tissue homeostasis in the intestine by enhancing epithelial cell proliferation and survival, and strengthening barrier function (Madsen et al. 2001; Ismail and Hooper 2005; Wentworth et al. 2011a; Jones et al. 2013; Alam et al. 2014, 2016). Indeed, mice raised in germfree conditions show many functional weak-

Editors: Gerard Karsenty and David T. Scadden

Additional Perspectives on Bone: A Regulator of Physiology available at www.perspectivesinmedicine.org

Copyright (C) 2018 Cold Spring Harbor Laboratory Press; all rights reserved; doi: 10.1101/cshperspect.a031203

Cite this article as Cold Spring Harb Perspect Med 2018;8:a031203 
nesses (Stappenbeck et al. 2002) and have impaired homeostasis (Pull et al. 2005).

The gut microbiome of humans and mice are quantitatively different but share a large qualitatively similar core (Krych et al. 2013). Because of these qualitative similarities, mice are extensively used to investigate the role of the microbiota in health and disease (Krych et al. 2013).

Numerous studies have shown differences in the microbiota of patients with and without a given inflammatory condition (Surana and Kasper 2014), although, in some cases, it remains unclear whether the observed dysbiosis is the cause or consequence of the underlying disease process (Surana and Kasper 2014). In addition, at least two metabolic diseases, obesity and diabetes, have been shown to have major determinants from the gut microbiome. In addition, alterations in the human microbiome are associated with various disease states. For example, decreased abundance of lactobacillus in the vaginal microbiome is associated with bacterial vaginosis (Ravel et al. 2011), and may also be associated with preterm labor (DiGiulio et al. 2015). Changes in the oral microbiome are associated with periodontal disease (Wang et al. 2013), and new associations with systemic disease such as rheumatoid arthritis (Scher et al. 2012) and cardiovascular disease are hypothesized. The skin microbiome is important in the development of atopic dermatitis and in the delayed wound healing that is a complication of diabetes (Grice et al. 2010). The gut microbiome the largest, richest, and most complex of the human microbiomes and is correspondingly the most well characterized and most investigated for disease associations. Gut microbes have been shown to modulate intestinal and systemic immune responses (Surana and Kasper 2014). For instance, gut-resident microbes have a robust influence on the emergence and/or maintenance of $\mathrm{CD}^{+}{ }^{+} \mathrm{T}$-cell subsets. Examples include the effects of specific bacteria on the emergence of T helper (Th) 17 cells (Ivanov et al. 2009) and the impact of Bacteroides fragilis in Th1 cells and Tregulatory (Treg) differentiation (Mazmanian and Kasper 2006). Changes in the gut microbiome are associated with risk for and progression of inflammatory bowel disease (Gevers et al. 2014), risk for colorectal cancer (Momozawa et al. 2011; Zhu et al. 2013), obesity (Turnbaugh et al. 2009), glucose control, and diabetes risk (Karlsson et al. 2013), and may even serve as a reservoir for antimicrobial resistance genes (Penders et al. 2013). However, more intriguing is evidence that the commensal microbes also influence immune responses distant from mucosal surfaces, including the central nervous system (CNS), joints, and lungs (Noverr et al. 2005; Wu et al. 2010; Lee et al. 2011; Surana and Kasper 2014). Involved mechanisms include regulation of nutrient absorption, regulation of intestinal barrier function and the resulting translocation of bacterial particles across the intestinal wall, and regulation of the immune response in the intestine systemically.

In the last 5 years, evidence has also emerged that the microbiota regulates bone homeostasis in health and disease. Multiple hypotheses have been postulated to explain how the microbiome affects bone (Hernandez et al. 2016). First, the response of the immune system to the microbiome results in the production of a variety of circulating cytokines and cell-based immune effectors that have profound effects on bone cells. Gut microbiota promotes bone formation, likely via an insulin-like growth factor (IGF)-1mediated mechanism (Schwarzer et al. 2016; Yan et al. 2016). The microbiome might also affect levels of steroid hormones, parathyroid hormone $(\mathrm{PTH})$, or vitamin $\mathrm{D}$ metabolites (Charles et al. 2015). Moreover, bacterial products may enter the circulation and directly influence bone cell function.

\section{DEFINITIONS AND KEY INVESTIGATIVE METHODOLOGIES}

Nearly all environments harbor distinct microbiomes, including the microenvironments of the human body. Although it has long been hypothesized that the human microbiome plays a key role in susceptibility to adverse health outcomes, it is only with recent technologies that comprehensive study is possible. Culture-based techniques still remain a foundational tech- 
nique in microbiology. However, many community members of the human microbiome cannot be cultured (Wade 2002). Because of this technical limitation, the diversity of the human microbiome has remained unknown until recently. Two key advances have enabled a more complete census of the human microbiome. The first advance that has made possible to define the human microbiome was an application of polymerase chain reaction (PCR)-based technology, which exploited features of the bacterial 16s ribosomal rRNA (rRNA) gene. This gene is comprised of constant, conserved regions, which flank variable regions. PCR primers that anneal to the constant regions can amplify the internal variable region from a diverse set of bacteria (Lane et al. 1985). These variable regions were sequenced and matched to a database to identify the organisms present. Recently, this DNA-based, culture-independent method gained substantial discriminating power when coupled to next-generation sequencing technology, which has the ability to sequence a population of PCR amplicons in a single experiment with single-molecule resolution (Shendure and Ji 2008). 16S-based sequencing is rapid and inexpensive enough to be applied to populationbased samples, and thus can be applied to (for example) case-control studies, or can be used to record longitudinal changes in microbiomes over time. This has created an explosion of data characterizing the microbiome, human and otherwise, with a vast array of applications from forensic science to translational health opportunities and beyond.

To impose order on the chaos of this data explosion, and encourage the development of companion bioinformatics tools necessary for data processing and analysis, two consortia were evolved. The European MetaHIT consortium was focused on the gut microbiome and its role in adverse health outcomes, including obesity and inflammatory bowel disease (Qin et al. 2010). In the United States, the Human Microbiome Project (HMP) was supported by the National Institutes of Health (NIH) Common Fund. In contrast to the MetaHIT consortium, the HMP focused on characterizing the healthy human microbiome, and creating a publicly available reference set of control data $(\mathrm{NIH}$ HMP Working Group et al. 2009; Human Microbiome Project Consortium 2012). The HMP sought to characterize five major human microbiome communities: the airway, skin, oral, gut, and vaginal microbiomes. Landmark studies from the HMP confirmed that different human microenvironments harbor distinct characteristic microbiomes that differ in $\alpha$ diversity and community membership.

Another critical advance has been the development of techniques for raising mice in germfree conditions. These animals are kept for the entire life in sterile isolators or individual sterile cages. Germ-free animals have several phenotypical abnormalities, including the presence of abnormal intestinal villi. Importantly, germ-free mice have an altered immune system resulting from the chronic lack of antigenic stimulation. For example, lymph nodes, spleens, and Peyer's patches of germ-free mice are relatively inactive. The tissues are small and contain rare, small, and indistinct germinal zones. Moreover, germ-free mice have fewer $\mathrm{T}$ cells, and effector T cells skewed toward a Th2 phenotype (Surana and Kasper 2014). Colonization of germ-free mice with wild-type microbiota or defined bacteria quickly reverses most of the phonetical and immunological abnormalities of germ-free mice, pointing to the role of microbiota in shaping intestinal and immune physiology. The immune system is stimulated by metabolites released by the gut flora and by direct interactions between immune cells and microorganisms (Belkaid and Hand 2014). Once activated in the intestine, immune cells are likely to migrate to peripheral lymphoid organs, including the bone marrow.

\section{MICROBIOTA AND BONE DENSITY}

\section{Microbiota Regulates Bone Growth and Bone Mass Acquisition}

Perhaps more intriguing than the capacity of a local microbiota to induce alterations in contiguous mucosal surfaces is evidence that the commensal microbes also influence immune responses distant from mucosal surfaces, in- 
cluding the CNS, joints, and lungs (Noverr et al. 2005; Wu et al. 2010; Lee et al. 2011; Surana and Kasper 2014). Involved mechanisms include regulation of nutrient absorption, intestinal barrier function and the resulting translocation of bacterial particles across the intestinal wall, and activation of the immune response in the intestine and systemically. Recently, evidence has also emerged that the microbiota regulates bone homeostasis in health and disease. Multiple hypotheses have been postulated to explain how the microbiome affects bone (Hernandez et al. 2016). First, the response of the immune system to the microbiome results in the production of a variety of circulating cytokines and cell-based immune effectors that have profound effects on bone cells. Gut microbiota promotes bone formation likely via an IGF-1-mediated mechanism (Schwarzer et al. 2016; Yan et al. 2016). The microbiome might also affect levels of steroid hormones, PTH, or vitamin D metabolites (Charles et al. 2015). Moreover, bacterial products may enter the circulation and directly influence bone cell function.

Initial investigations by Sjogren et al. (2012) revealed that female germ-free mice have higher cortical and trabecular bone mass compared with control mice raised in conventional conditions. Germ-free mice had fewer $\mathrm{CD} 4{ }^{+} \mathrm{T}$ cells and osteoclast precursors in the bone marrow, had lower levels of osteoclastogenic cytokines, and, at 9 weeks of age, the trabecular bone mass of germ-free mice was 39\% higher than that of controls. Importantly, the high bone mass and the immune abnormalities of germ-free mice were reversed by reconstitution of the gut microbiota with flora from conventionally raised microbial-replete mice (Sjogren et al. 2012). Corroborating these observations, we found that 20-week-old female germ-free C57Bl/6 mice have higher trabecular bone volume than congenic age-matched mice raised in conventional conditions ( $\mathrm{Li}$ et al. 2016). Furthermore, germ-free mice had increased femoral cortical volume compared with conventionally raised mice (Li et al. 2016). Surprisingly, opposite effects were reported in a study conducted in 8week-old germ-free BALB/c male mice. These mice were found to have lower cortical and tra- becular volume as compared with congenic conventionally raised mice (Schwarzer et al. 2016). Mechanistic studies revealed that in male BALB/c mice the microbiota confers higher sensitivity to the bone anabolic growth factor IGF-1 (Schwarzer et al. 2016). These findings indicate that mouse strain, age, and sex influence the impact of the microbiome on bone mass. Another possibility is the presence different microbiomes among mouse strains. Adding further complexity to this issue, bacterial colonization of adult CB6F1 mice was found to stimulate bone resorption and decrease bone mass in the first 4 weeks after colonization (Yan et al. 2016). However, long-term colonization leads to an equalization of bone mass, indicating that duration of colonization is another critical variable that influences bone turnover and bone mass (Yan et al. 2016). To determine whether endogenous microbiota contributes to the regulation of bone remodeling under baseline homeostatic conditions, the same investigators treated conventionally raised mice with antibiotics. The resulting depletion of the microbiota was associated with an increase in bone mass and a decrease in bone turnover (Yan et al. 2016), confirming that in a short-term setting the ablation of the microbiota increases bone mass, whereas reconstitution of the microbiota in former germ-free mice causes bone loss.

These studies are in apparent conflict with a serious of investigations conducted to analyze the effect of malnourishment on body growth and skeletal development. Analysis of stool samples from children from Malawi with severe malnutrition revealed the presence of an immature microbiome. Colonization of germ-free mice with such immature microbiomes resulted in suboptimal body growth and shorter bones, whereas germ-free mice on the same diet given "mature" microbiomes of healthy children underwent normal body growth (Blanton et al. 2016). Surprisingly, colonization of germ-free mice with stools from malnourished children caused an increased in cortical bone density (Blanton et al. 2016). Germ-free mice colonized with stools from healthy 6-month-old children acquired a higher bone density than those colonized with stools from healthy 18-month-old 
children (Blanton et al. 2016), further suggesting that immature microbiota induces bone anabolism.

In a similar investigation, the blunted skeletal development of germ-free mice was partially reversed by colonization with selected lactobacilli (Schwarzer et al. 2016). Another study revealed that sialylated human milk oligosaccharides (HMOs) are significantly less abundant in the milk of mothers with severely malnourished infants (Charbonneau et al. 2016). HMOs are not significant nutrients for humans, but gut bacteria use HMOs as an energy source. Colonization of germ-free mice with stools from 6-month-old stunted Malawian infants resulted in blunted body growth. Feeding the colonized mice with HMOs produced a microbiota-dependent augmentation of lean body mass gain, and altered liver, muscle, and brain metabolism in ways indicative of a greater ability to use nutrients for anabolism (Charbonneau et al. 2016). Among the changes induced by HMOs supplementation was an increase in bone volume (Charbonneau et al. 2016), indicating that positive modification of the microbiota induced by a prebiotic substance stimulates bone growth. Together, these studies show that changes in the microbiota independently regulate bone growth and bone mass acquisition.

Evidence for the critical influence of the gut microbiota on bone growth is supported by studies that used antibiotic treatment of mice. Initial investigations revealed that short-term administration of subtherapeutic doses of antibiotics at weaning resulted in elevated levels of bone mass (Cho et al. 2012). Corroborating results were generated in a study showing that a low dose of penicillin from birth to weaning increases bone mass in adult mice (Cox et al. 2014). More recently, investigations confirmed that reduction of intestinal bacteria by vancomycin treatment increases bone mass (Yan et al. 2016). In addition, administration of a cocktail of tetracyclines was found to prevent ovariectomy-induced bone loss (Williams et al. 1996). Some antibiotic studies revealed unexpected differences on the bone response to microbiota reduction in male and female mice (Cox et al. 2014). Moreover, an increase in bone density in response to antibiotics was more consistently observed in young animals (Cho et al. 2012; Nobel et al. 2015). Intriguingly, low-dose antibiotics are commonly fed to chicken, cows, and pigs to increase size and body weight, and it would be interesting to determine how much of the increased weight gain is the result of increases in bone density (Cromwell 2002). At any rate, these studies clearly show that antibiotic treatment influences bone mass. Because antibiotics lower the number of bacteria, and/or alter the diversity of microbial taxa within the intestinal lumen, it can be inferred that the bacterial load and diversity within the gut are significant, contributing variables to the mechanisms by which the gut microbiota regulates bone mass.

It is also known that considerable variation exists in the microbiome of mice housed in different facilities and/or fed different types of chow (Ericsson et al. 2015; Laukens et al. 2016; Stappenbeck and Virgin 2016). Therefore, the diversity of the microbiome in the particular facility is a potential confounding factor to data interpretation when assessing the influences of the microbiome on bone density. For example, at sacrifice, the trabecular bone volume of the conventionally raised mice used in our studies was $>50 \%$ of that of the BALB/c male mice used by Schwarzer et al. (2016). Further attesting to the relevance of local housing conditions, in preliminary studies, we found $\mathrm{C} 57 \mathrm{Bl} / 6$ mice purchased from Jackson Laboratory to have a higher bone volume than isogenic mice bought from Taconic Biosciences. However, following 4 weeks of cohousing in our animal facility, the bone volume of mice from Jackson Laboratory decreased to the level of that of Taconic Biosciences mice. Because mice are coprophagic, and transfer their microbiomes from mouse to mouse by this behavior, the bone density decrease observed in mice from the Jackson Laboratory is perhaps the result of colonization of Jackson Laboratory mice with fecal material from Taconic Biosciences mice. These observations clearly point to the critical need to account for reciprocal host-microbiome interactions in experimental approaches that investigate the microbiome and bone density. 
R. Pacifici

Microbiota and the Bone Loss Induced by Sex Steroid Deficiency

Postmenopausal osteoporosis is a common skeletal disease leading to fracture and disability that stems from the cessation of ovarian function at menopause and from genetic and nongenetic factors that heighten the impact of estrogen deficiency on the skeleton (Riggs and Melton 1983, 1986). Fractures caused by osteoporosis have devastating consequences, particularly in the elderly. Vertebral fractures are a source of significant pain and crippling, whereas hip fractures lead to mortality rates of $24 \%-$ $30 \%$ in the first year alone. Furthermore, almost $50 \%$ of survivors suffer permanent disability (Cummings and Melton 2002; Johnell and Kanis 2006; Lewis et al. 2006; Burge et al. 2007). Declining estrogen levels at menopause results in a potent stimulation of bone resorption and, to a lesser extent, bone formation leading to a period of rapid bone loss (Zaidi 2007). This initial phase is followed by a slower but more prolonged period of bone loss that affects mostly the cortical compartment of the skeleton. Androgen deficiency also results in reduced trabecular and cortical bone density (Finkelstein et al. 1987). Androgen receptor signaling contributes to the maintenance of trabecular and cortical bone (Venken et al. 2006). Furthermore, men with complete androgen insensitivity have diminished bone density, confirming the obligatory role for androgens in the maintenance of bone density in men (Sobel et al. 2006). However, it is now clear that androgens regulate bone homeostasis in men mostly via their peripheral conversion to estrogen (Finkelstein et al. 2016) and that estrogen deficiency has a dramatic effect on bone homeostasis in men (Bilezikian et al. 1998; Fink et al. 2006). In female mice, the acute effects of sex steroid deficiency are modeled by ovariectomy (ovx), or treatment with gonadotrophin-releasing hormone (GN-RH) agonists (Kurabayashi et al. 1993; Wang et al. 2000).

At the cellular level, the central mechanism by which sex steroid deficiency induces bone loss is an increase in osteoclast formation (Sun et al. 2006; Weitzmann and Pacifici 2006) and osteoclast life span (Nakamura et al. 2007; Krum et al. 2008). The primary driver of increased osteoclastogenesis is the enhanced production of the immune factors receptor activator of nuclear factor $\kappa \mathrm{B}$ ligand (RANKL) and tumor necrosis factor (TNF) (Pacifici 2012; Khosla and Pacifici 2013). Therefore, sex steroid-dependent bone loss is regarded as a form of inflammatory bone loss (Weitzmann and Pacifici 2006; Khosla and Pacifici 2013). Many cell types have been shown to be generators of RANKL, including hemopoietic cells, T cells, B cells, osteoblastic cells, and osteocytes (Eghbali-Fatourechi et al. 2003; Taxel et al. 2008; Xiong et al. 2011). In the mouse, osteocytes are probably the most relevant source of RANKL in estrogen-deficient mice (Xiong et al. 2011). In humans, estrogen deficiency is associated with an expansion of RANKL and TNF-expressing T cells and $B$ cells (Eghbali-Fatourechi et al. 2003; D'Amelio et al. 2008; Taxel et al. 2008; Adeel et al. 2013). The contributing influences of interleukin (IL)-1 and TNF in humans was underscored by reports showing that menopause increases the levels of both of these immune factors (Pacifici et al. 1989, 1991; Cohen-Solal et al. 1993; Bernard-Poenaru et al. 2001), whereas treatment with TNF and IL-1 inhibitors prevents the increase in bone resorption that results from estrogen deficiency (Charatcharoenwitthaya et al. 2007). Indeed, the causal role of TNF in ovxinduced bone loss in mice has been shown in multiple models (Ammann et al. 1997; Kimble et al. 1997; Roggia et al. 2001), in which the key mechanisms by which TNF stimulates bone resorption were identified as the potentiation of RANKL activity (Cenci et al. 2000; Lam et al. 2000) and induction of Th17 cells (Chen et al. 2011; Sugita et al. 2012; Li et al. 2015). Th17 cells are an osteoclastogenic population of $\mathrm{CD}^{+}$ cells (Sato et al. 2006; Miossec et al. 2009) defined by the capacity to produce IL-17 (Basu et al. 2013). Th17 cells potently induce osteoclastogenesis by secreting IL-17A, RANKL, TNF, IL-1, and IL-6, along with low levels of interferon $\gamma$ (IFN- $\gamma$ ) (Jovanovic et al. 1998; Waisman 2011; Komatsu and Takayanagi 2012). IL-17A stimulates the release of RANKL by all osteoblastic cells, including osteocytes (Kotake et al. 
1999; Li et al. 2015), and increases the osteoclastogenic activity of RANKL by up-regulating RANK (Adamopoulos et al. 2010). Intriguingly, postmenopausal women with osteoporosis show elevated levels of serum IL-17 (Molnar et al. 2014a,b; Zhang et al. 2015). In mice, ovx expands Th17 cells by promoting the differentiation of naïve $\mathrm{CD}^{+}$cells into mature Th17 cells (Tyagi et al. 2012a), a phenomenon driven by cytokines such as transforming growth factor $\beta$ (TGF- $\beta$ ), IL-6, IL-1 $\beta$, and TNF (Veldhoen et al. 2006; Chen et al. 2011; Sugita et al. 2012; Basu et al. 2013), factors that are all dysregulated by estrogen deficiency (Pacifici 2012). In addition, Th17 differentiation is inhibited by estrogen via a direct effect on CD $4^{+} \mathrm{T}$ cells mediated by estrogen receptor (ER) $\alpha$ (Lelu et al. 2011). The importance of IL-17 in bone loss is highlighted by the fact that silencing of IL-17R (DeSelm et al. 2012) or treatment with anti-IL-17 antibody (Tyagi et al. 2014) prevent ovx-induced bone loss.

Evidence now suggests that T-cell-produced TNF functions in a pivotal role in the mechanism of ovx-induced bone loss based on the finding that no bone loss occurred, and no increased TNF production was detected in T-cellnull mice, or mice depleted of $\mathrm{T}$ cells (Cenci et al. 2000; Li et al. 2011). Furthermore, bone loss did not occur in mice lacking T-cell TNF production (Cenci et al. 2000; Roggia et al. 2001; Gao et al. 2004, 2007), or lacking the costimulatory molecule CD40L (Li et al. 2011), as well as mice treated with CTLA4-Ig, an agent that transmits an inhibitory signal to T cells (Grassi et al. 2007). These findings have been confirmed by other laboratories (Yamaza et al. 2008; Tyagi et al. 2012b). Moreover, symmetrical evidence is emerging from human studies in favor of a role for T-cell-produced TNF in postmenopausal bone loss (D'Amelio et al. 2008; Adeel et al. 2013). Mechanistically, ovx induces proliferation of conventional $\mathrm{T}$ cells via an antigen-dependent process (Cenci et al. 2003; Grassi et al. 2007) thereby increasing the number of $\mathrm{CD} 4^{+}$ and $\mathrm{CD} 8{ }^{+} \mathrm{T}$ cells in the bone marrow $(\mathrm{BM})$ and enhancing their production of TNF (Roggia et al. 2001; Li et al. 2011). This process is driven by enhanced antigen presentation by macro- phages and dendritic cells (Cenci et al. 2003; Grassi et al. 2007), although the nature of the involved antigen remains unknown.

Because the T cells of ovx mice have features that resemble those of T cells exposed to bacteria (Surh and Sprent 2008), it is plausible that increased exposure to microorganisms provides the antigens required for $\mathrm{T}$-cell activation and ensuing systemic immune responses required for sex steroid-deficiency-induced bone loss. This hypothesis was tested in a study using mice raised in germ-free conditions. Mice raised in conventional conditions and germ-free mice colonized with the microbiota of conventional microbial-replete mice, were used as control groups. In addition, because ovx is not technically feasible in germ-free conditions, sex steroid deficiency was induced pharmacologically using the GN-RH agonist leuprolide. This investigation revealed that germ-free mice are entirely protected against the loss of trabecular bone induced by sex steroid deprivation (Fig. 1) (Li et al. 2016). Importantly, colonization of germ-free mice with flora from conventionally raised animals led to bone loss in response to sex steroid deprivation, showing that the protection of germ-free mice against bone loss is not caused by intrinsic, irreversible immune abnormalities conferred by the germ-free status. In contrast, leuprolide treatment resulted in a similar loss of cortical bone in all tested groups of conventional bacterial-replete mice, indicating that sex steroid deprivation induces cortical bone loss that occurs by a microbiota-dependent mechanism ( $\mathrm{Li}$ et al. 2016). This is probably because of the fact that $\mathrm{T}$ cells reside in the proximity of trabecular and endosteal surfaces (Fujisaki et al. 2011), but have no contacts with periosteal surfaces and have limited capacity to communicate with osteocytes. Further attesting to the role of the microbiota as regulator of bone turnover, leuprolide increased bone resorption in conventional and colonized mice, but not in germfree mice. In addition, germ-free sex steroiddepleted mice had lower rates of compensatory bone formation than conventional sex steroiddepleted mice (Li et al. 2016).

Assessment of cytokine production revealed that sex steroid deficiency expands TNF- and 


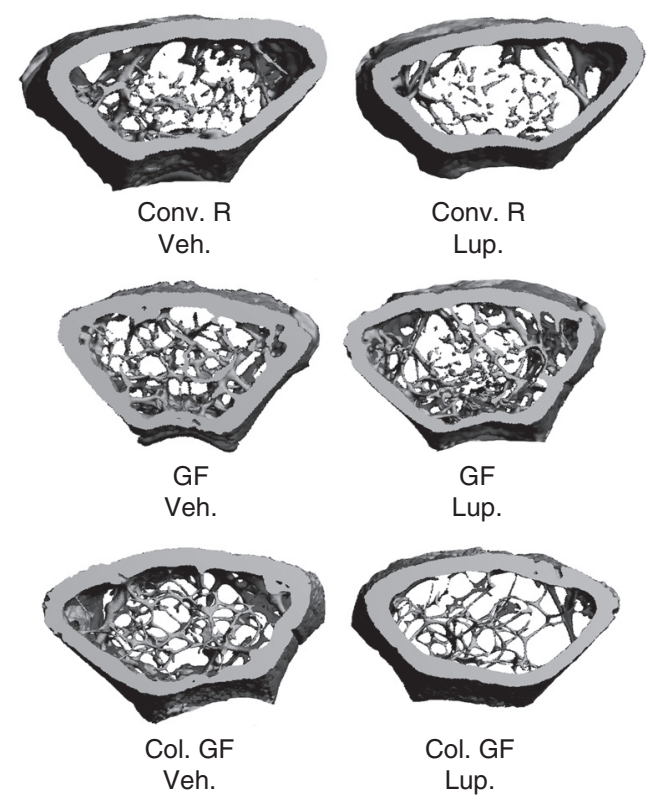

Figure 1. Germ-free (GF) mice are protected against the loss of trabecular bone induced by sex steroid deficiency. Three-dimensional reconstructions of femoral bone by in vitro microcomputed tomography in conventionally raised (Conv. R) mice, GF mice, and colonized GF (Col. GF) mice following treatment with the gonadotrophin-releasing hormone (GN-RH) agonist leuprolide (Leu) or vehicle control for 10 weeks. The images show that GF mice are protected against the loss of trabecular bone induced by sex steroid deficiency. (From Gao et al. 2007; reproduced, with permission, from the Journal of Clinical Investigation (C) 2007.)

IL-17-producing T cells and increases the levels of TNF, RANKL, and in the bone marrow and small intestine of conventionally raised mice. In contrast, in germ-free mice, no increase in TNF, RANKL, and IL-17 production occurred in the bone marrow or in the tissues of the small intestine following sex steroid deficiency (Li et al. 2016). Overall, the data showed that the microbiota is required for sex steroid deprivation to induce bone loss. Moreover, the data indicated that this may occur as a result of the gut microbiome driving the expansion of intestinal $\mathrm{T}$ cells and Th17 cells, which produce TNF, RANKL, and IL-17.

It is still unclear whether the bone loss is induced by cytokines produced by immune cells in gut, which then circulate to the bone, induced by immune cells activated in the gut that traffic to the bone marrow, or induced by bone marrow cells that are activated by foreign antigens of intestinal origin. Bacterial translocation, the passage of viable bacteria across the intestinal wall into the systemic circulation is a recognized phenomenon, although very rare in healthy individuals (O'Boyle et al. 1998). Because live bacteria are unlikely to travel far from the intestine, it is unlikely that activation of immune cells in the bone marrow is caused by direct exposure to bacteria or bacterial particles. Based on preliminary cell migration studies, it appears likely that immune cells, first activated in the intestine, home to the bone marrow where they produce osteoclastogenic cytokines.

\section{The Influence of Gut Permeability on Bone Loss}

The intestinal epithelium is the interface between the mammalian host and the luminal microbiota. The intestine controls molecular trafficking between the lumen and the epithelial submucosa through paracellular space, which under physiological conditions exclude the passage of molecules with a radius of $>15 \AA$ ( $\sim 3.5 \mathrm{kDa}$ for oligopeptides) (Fasano 2012). The intestinal wall is in intimate contact with the gut luminal microbiota and constantly samples and responds to the antigenic load within the intestinal lumen (McDole et al. 2012). Increased permeability allows an expanded range of molecules and potential antigenic load to enter epithelial submucosa, which may initiate aberrant intestinal and systemic proinflammatory responses (Hijazi et al. 2004; Fasano 2012; Heyman et al. 2012; Teixeira et al. 2012). Thus, maintaining a tight selective physiological barrier between the gut lumen and submucosa is essential for health. This is criti$\mathrm{cal}$ in the context of bone homeostasis because osteoclastogenic cytokines are produced by immune cells that reside in intestinal subepithelial compartments of the intestine, and any change in gut permeability is thus likely to elevate levels of osteoclastogenic cytokines and influence bone density. 
Bone Remodeling and the Microbiome

Recent studies have shown that sex steroid deficiency increases gut permeability thus weakening barrier integrity (Raehtz et al. 2014; Li et al. 2016), leading to increased bacterial translocation and increased levels of inflammatory markers (Fig. 2). Specifically, sex steroid deficiency results in reduced transcript levels of a number of the gap junction proteins of the claudin family such as claudin 2, 3, and 15, and of JAM3, which have all been shown to modulate intestinal barrier integrity (Zeissig et al. 2007; Ulluwishewa et al. 2011). Also, serum endotoxin levels, which correlate with gut permeability, are elevated in sex steroid-deprived mice. Furthermore, ovx mice have higher levels of orally administered 4-kDa FITC-dextran in their serum, which is a standard assay for gut permeability, confirming that the intestinal barrier permeability is compromised following sex steroid depletion. Together, these reports suggest that increased gut permeability caused by sex steroid depletion results in an increased antigenic load entering the epithelial submucosa, thereby initiating the activation of immune cells and the local production of osteoclastogenic cytokines. Because sex steroids have been inferred to function in maintaining a tight physiological barrier between the systemic tissue compartments and the resident flora of the gut lumen (Wada-Hiraike et al. 2006), depleted levels of sex steroids would thereby increase gut permeability. This notion offers a solid link between a weakened intestinal barrier and the signature osteoclastogenic cytokine profile associated with osteoporosis. Moreover, any therapeutic approach that can tighten gut permeability would offer a promising therapy for preventing sex steroiddepletion-induced bone loss.

\section{The Influence of Probiotic Therapy on Bone Mass and Bone Turnover}

Numerous drugs are currently Food and Drug Administration (FDA)-approved for the prevention and treatment of osteoporosis. However, most cases in the United States remain untreated or ineffectively treated because of cost and/or adverse events of currently available drugs, leading to inadequate prescriptions of and poor compliance with anti-osteoporosis medications (Jha et al. 2015; Khosla and Shane 2016). For example, despite clear efficacy of bisphosphonate drugs in the secondary prevention of hip fracture, a recent large study in patients with hip fracture found that use of bisphosphonates decreased from an already dismal 15\% in 2004 to an abysmal 3\% in 2013 (Kim et al. 2016), most likely because the available anti-osteoporotic drugs cause a variety of adverse outcomes. Some of these, like osteonecrosis of the
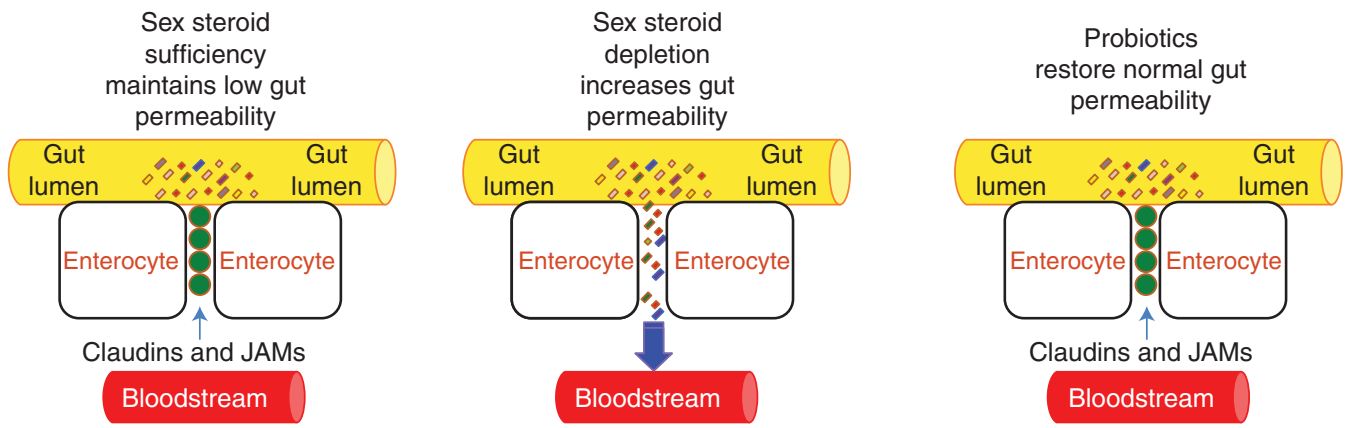

Figure 2. Diagrammatic representation of the effects of sex steroid deficiency on gut permeability. In physiologic conditions, proteins of the JAMs and claudin family seal the space between intestinal epithelial cells preventing bacteria and bacterial products from penetrating the intestinal wall and activating immune cells. Sex steroid deprivation down-regulates the expression of gap junction proteins, leading to increased gut permeability. The resulting increased bacterial translocation induces a local and systemic immune response that causes an increased production of osteoclastogenic cytokines. Probiotic supplementation up-regulates expression of claudins and JAMs, thus restoring normal gut barrier function. 
jaw and atypical subtrochanteric fractures, may result from decreased rates of bone resorption. Safety concerns with teriparatide limit its use to 24 months. Drugs under development also have significant concerns. Odanacatib, a cathepsin K inhibitor, was recently abandoned by its manufacturer because of an increased incidence of cerebral vascular accidents. Romosozumab, an antisclerostin antibody, only transiently stimulates bone formation and appears to behave subsequently like an antiresorptive agent. Abaloparatide, a parathyroid hormone-related protein (PTHrP) analog, is similar in its actions and route of administration to teriparatide and, like the latter, will be limited to use for no more than 2 years. These data underscore the critical need to identify inexpensive, safe, and effective interventions for both the prevention and treatment of osteoporosis. Probiotics, defined as viable microorganisms that confer a health benefit when administered in adequate quantities (Salminen et al. 1999), may represent such an innovative strategy. Indeed, based on observations of microbiome influences on metabolic dysfunction, there is reason to hypothesize that the community of commensal microbes that reside in the gut may represent one potentially modifiable factor that could alter skeletal status.

Probiotics have been shown to alter the composition and/or the metabolic activity of the gut microbiota (Bron et al. 2012), regulate the immune responses in the host (ScholzAhrens et al. 2007; Yan and Polk 2011), and enhance epithelial barrier function (Seth et al. 2008; Anderson et al. 2010). These effects account for the emerging beneficial effects of probiotics for bone health. Several studies have been conducted to evaluate the effects of probiotics in intact animals. For example, probiotics have been shown to increase bone mass in chickens (Mutus et al. 2006) and prevent alveolar bone loss in rats (Tomofuji et al. 2012). Moreover, male rats fed with fermented milk containing Lactobacillus helveticus had higher bone density than controls (Narva et al. 2004), whereas treatment with Lactobacillus reuteri 6475 increased bone mass by decreasing bone resorption and TNF levels. Interestingly, these beneficial effects were found in male but not in female mice (McCabe et al. 2013). A follow-up study from the same group revealed that $L$. reuteri 6475 increases bone density in female mice but only under the inflammatory conditions induced by surgical stress (Collins et al. 2016). That investigation revealed that the skin incision required for sham-ovariectomy induces a longlasting inflammatory state that increases the expression of inflammatory cytokines in the intestine and the bone marrow. The presence of this inflammatory state appeared to be required for L. reuteri 6475 to increase bone mass but the exact mechanism of this phenomenon remains unknown. Because increased activation of bone remodeling units is followed by a period of intense bone formation, the latter observation could be explained by the fact that sham-operated mice sustain an increase in activation frequency induced by inflammatory cytokines, followed by a period of intense bone formation. Probiotics may also blunt the amount of resorbed bone and potentiate bone formation. In nonoperated mice, $L$. reuteri 6475 may be unable to suppress bone resorption below baseline and thus may be unable to stimulate bone formation.

A beneficial effect of probiotics in preventing the bone loss induced by ovx has also been reported by many laboratories. An early study showed that Lactobacillus-fermented soymilk prevents trabecular bone loss as effectively as the bisphosphonate alendronate (Chiang and Pan 2011). Shortly thereafter, Ohlsson et al. (2014) reported that a single Lactobacillus strain or a mixture of three lactobacilli prevents the loss of cortical bone and the increase in bone resorption induced by ovx. The same studies revealed that the bone-sparing effects of lactobacilli was related to blunted production of TNF and IL- 1 and a reversal of the decrease in Treg cells induced by ovx (Ohlsson et al. 2014). Surprisingly, the same investigation showed no protection against ovx-induced trabecular bone loss (Ohlsson et al. 2014). Britton et al. (2014) confirmed the bone-sparing activity of probiotics by reporting that $L$. reuteri prevents ovxinduced trabecular bone loss. This probiotic prevented the increase in $\mathrm{CD} 4^{+} \mathrm{T}$ cells induced by ovx, induced secretion of anti-TNF factors, 
Bone Remodeling and the Microbiome

and modified microbial communities in the ovx mouse gut (Britton et al. 2014).

In a study by our research group, 10-weekold conventionally raised mice were ovx or sham operated and treated with probiotics or control vehicle for the first 4 weeks after surgery, and then sacrificed. Mice were supplemented by oral gavage with vehicle or purified cultures of the extensively studied probiotic Lactobacillus rhamnosus GG (LGG), or with commercially available VSL\#3 preparation, which contains eight strains of live bacteria, namely, Bifidobacterium breve, Bifidobacterium longum, Bifidobacterium infantis, Lactobacillus acidophilus, Lactobacillus plantarum, Lactobacillus paracasei, Lactobacillus bulgaricus, and Streptococcus thermophilus during a 4-week period. Mice were fed with probiotics twice a week for 4 weeks. The probiotics LGG and VSL\#3 prevented ovxinduced bone loss (Fig. 3) and decreased gut permeability and intestinal and systemic inflammation ( $\mathrm{Li}$ et al. 2016). Moreover, LGG and VSL\#3 increased bone mass in estrogen-replete mice by stimulating bone formation ( $\mathrm{Li}$ et al. 2016). These profound effects were elicited by oral administration of either LGG or VSL\#3 to ovx mice with a conventional microflora. These data indicate that both LGG and VSL\#3 have dynamic interactions with the epithelial layer of the intestine, and actively induce the expression of proteins involved with tightening the gut epithelial barrier. In addition, it is also possible that probiotics function by displacing bacterial species that down-regulate tight junctional proteins in the intestinal epithelium.

Critical control assays in our studies showed that protection against bone loss is bacterialstrain-specific. Here, treatment of ovx mice with an attenuated laboratory strain of Escherichia coli $\mathrm{DH} 5 \alpha$ (a strain that does not exert a

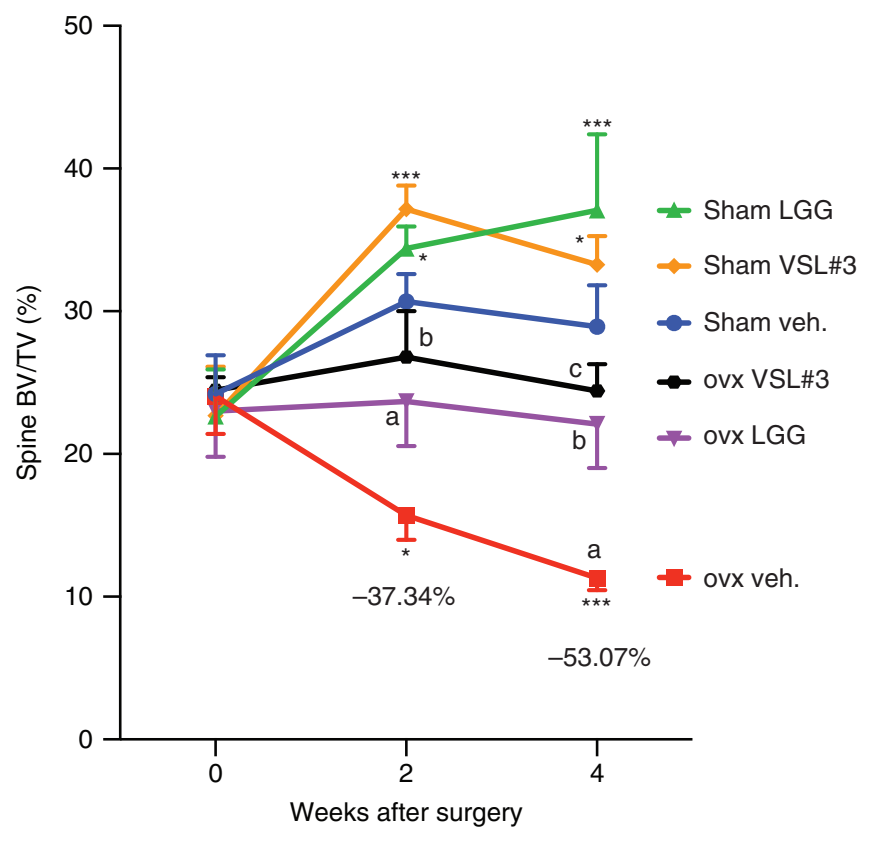

Figure 3. Probiotic supplementation prevents sex steroid-induced bone loss. Conventional ovariectomized (ovx) and sham-operated mice were supplemented twice a week with VSL\#3, Lactobacillus rhamnosus GG (LGG), or vehicle (veh.). The figure shows in vivo prospective measurements of spinal bone volume $(\mathrm{BV} / \mathrm{TV})$, as measured by microcomputed tomography $(\mu \mathrm{CT})$ scanning at baseline and 2 and 4 weeks after surgery. $n=10-14$ mice per group. Data are expressed as mean \pm SEM. $\mathrm{a}=p<0.05, \mathrm{~b}=p<$ 0.01 , and $\mathrm{c}=p<0.001$ compared with baseline. ${ }^{*} p<0.05$ and ${ }^{* * *} p<0.001$ compared with sham vehicle. (From Cenci et al. 2000; reproduced, with permission, from the Journal of Clinical Investigation (C) 2000.) 
probiotic effect) exerted no detectable modulatory influence on bone loss or on cytokine production. Intriguingly, treatment of ovx mice with the LGG pili mutant $\operatorname{LGG}(\Delta \mathrm{SpaC})$, referred to herein as LGGM, partially protected ovx mice form bone loss. The SpaC protein is necessary for LGG to bind to the intestinal mucus layer, and for LGG to exert its positive influence on gut tissue health (Ardita et al. 2014). The fact that LGGM still maintained a degree of protection from bone loss suggests that direct contact with the mucus layer may not be the only mode by which LGG exerts probiotic effects, and that other properties of LGG, such as the production of short chain fatty acids, which have been shown to modulate cytokine levels in the intestine, is also a mechanism to consider (Asarat et al. 2015).

LGG has been shown to facilitate stem-cell turnover (Jones et al. 2013), to facilitate wound restitution in the gut (Alam et al. 2014), and mediate cytoprotective effects in the gut (Jones et al. 2012, 2015) and cell proliferation and migration (Wentworth et al. 2010, 2011b). It is also known that permeability along paracellular spaces in the epithelium is controlled by intercellular tight junctional proteins (Ma and Anderson 2006; Yu and Yang 2009) and regulated, at least in part, by the mitogen-activated protein kinase (MAPK) and phosphoinositide (PI)3-kinase signaling pathways (Wang et al. 2004). This may suggest that contact of epithelium cells with LGG and VSL\#3 is able to compensate for the loss of MAPK activity following sex steroid depletion (Filardo et al. 2000). Because gut epithelial cells express ERs (Armstrong et al. 2013; Qin et al. 2014) and ER signaling activates MAPK (Filardo et al. 2000), it is likely that sex steroids binding to their receptors in the gut epithelia induce MAPK expression that eventuates in maintaining and/or tightening gut permeability. Sex steroid deficiency would then result in weakening the MAPK pathway expression and barrier integrity, as detected in ovx or leuprolide-treated mice.

A relationship between decreased taxonomic diversity and disease state has been found in many inflammatory (Gevers et al. 2014; Scher et al. 2015) and metabolic conditions (Knip and
Siljander 2016). As a result, decreased diversity is regarded as an indicator of a disease state, reflecting a deteriorating habitat and/or depleted resources (Cardinale et al. 2012). Interestingly, estrogen depletion has also been associated with decreased $\alpha$ diversity in the gut microbiome (Flores et al. 2012; Fuhrman et al. 2014), whereas microbial diversity in the gut transiently increases with administration of probiotics (Preidis et al. 2012). Therefore, we hypothesize that sex steroid deficiency may lead to decreased microbiota diversity and that LGG and VSL\#3 probiotics restore a greater diversity. Further studies will be required to investigate this hypothesis and to determine whether decreased diversity contributes to the bone loss induced by sex steroid deprivation. In summary, the dysregulation in the interactions between the gut microbiota and the intestinal wall play a pivotal role in inducing inflammation and bone loss in sex steroid-deficient mice. Direct clinical applications of these findings arise because of the availability of pre- and probiotic agents that may prevent bone loss by tightening the gut barrier integrity, thus limiting the production of osteoclastogenic cytokines.

\section{PREBIOTICS AND BONE}

Prebiotics are nondigestible fermentable food ingredients that promote the growth of beneficial microbes and/or promote beneficial changes in the activity of the microbiome (Gibson et al. 2004). Although nondigestible by humans, prebiotics are metabolized by bacteria. Prebiotics are found in a variety of foods such as artichokes, garlic, leeks, dandelion greens, bananas, onions, and chicory (McCabe et al. 2015). In many cases, a significant amount of the food is needed to get enough prebiotic for activity; therefore, prebiotics such as inulin have been developed into soft chew, capsule, tablet, or shake forms (McCabe et al. 2015). Prebiotics include nondigestible oligosaccharides such as polydextrose, fructo-oligosaccharides (FOSs), inulin, xylo-oligosaccharides, galacto-oligosaccharides (GOS), and soybean oligosaccharides. Prebiotics have been found to increase calcium absorption in healthy animals (Weaver et al. 
2010; Legette et al. 2012) and humans (Griffin et al. 2002; Abrams et al. 2005). Prebiotics have also been found to increase calcium absorption in ovx animals (Zafar et al. 2004) and postmenopausal women (van den Heuvel et al. 2000). More importantly, FOS and inulin have been found to increase indices of trabecular and cortical bone volume and structure in healthy mice (Garcia-Vieyra et al. 2014) and rats (Takahara et al. 2000; Roberfroid et al. 2002). Similarly, prebiotics have also been shown to prevent ovx-induced bone loss in experimental animals (Chonan et al. 1995). Studies in humans have revealed that prebiotics increase whole-body bone mineral density in adolescent girls (Abrams et al. 2005) and decrease bone loss in postmenopausal women (Slevin et al. 2014). Prebiotics appear to affect both bone formation and bone resorption. The mechanism of action of prebiotics in bone remains unknown. However, it is likely that metabolic and immunological pathway may be involved (Weaver 2015). First, dietary fiber is fermented to short-chain fatty acids (SCFAs) in the lower gut by resident microbiota. SCFAs lower intestinal $\mathrm{pH}$, which causes an increase in calcium absorption (Weaver 2015). Moreover, SCFAs serve as energy sources for gut epithelial cells, and this may lead to improved gut health and gut barrier function (Donohoe et al. 2011). Importantly, SCFAs modulate cytokine production and induce expansion of Treg cells (Arpaia et al. 2013; Furusawa et al. 2013; Smith et al. 2013) through multiple mechanisms (Zeng and Chi 2015). In fact, SCFAs have been implicated in anti-inflammatory properties of a mix of $17 \mathrm{hu}$ man-derived Clostridia strains. Tregs have been shown to regulate osteoclast formation (Kim et al. 2007; Zaiss et al. 2007; Kelchtermans et al. 2009); thus, SCFAs may regulate bone resorption via Tregs.

\section{CONCLUSIONS}

In the last 5 years, numerous links have emerged between the intestinal microbiota and bone health. Most critical data have been obtained in experimental animals and confirmation in humans is needed. In particular, prospective clinical trials remain to be conducted to establish the efficacy of prebiotics and probiotics in preventing age- and menopause-related bone loss and to increase bone mass in growing children and adults.

Another area ripe for development is a comparison of the composition of the intestinal microbiota in healthy individuals and osteoporotic subjects with and without fractures. These studies may reveal whether microbiota alterations leading to a predisposition to bone loss and fracture exist or not, and whether microbiota sequencing may be used as a novel biomarker for osteoporosis. Colonization of germfree animals with intestinal microbiota from healthy and osteoporotic subjects will further help in establishing the role of specific microbiota alterations in postmenopausal- and agerelated bone loss.

\section{REFERENCES}

Abrams SA, Griffin IJ, Hawthorne KM, Liang L, Gunn SK, Darlington G, Ellis KJ. 2005. A combination of prebiotic short- and long-chain inulin-type fructans enhances calcium absorption and bone mineralization in young adolescents. Am J Clin Nutr 82: 471-476.

Adamopoulos IE, Chao CC, Geissler R, Laface D, Blumenschein W, Iwakura Y, McClanahan T, Bowman EP. 2010. Interleukin-17A upregulates receptor activator of NF-кB on osteoclast precursors. Arthritis Res Ther 12: R29.

Adeel S, Singh K, Vydareny KH, Kumari M, Shah E, Weitzmann MN, Tangpricha V. 2013. Bone loss in surgically ovariectomized premenopausal women is associated with T lymphocyte activation and thymic hypertrophy. J Investig Med 61: 1178-1183.

Alam A, Leoni G, Wentworth CC, Kwal JM, Wu H, Ardita CS, Swanson PA, Lambeth JD, Jones RM, Nusrat A, et al. 2014. Redox signaling regulates commensal-mediated mucosal homeostasis and restitution and requires formyl peptide receptor 1. Mucosal Immunol 7: 645-655.

Alam A, Leoni G, Quiros M, Wu H, Desai C, Nishio H, Jones RM, Nusrat A, Neish AS. 2016. The microenvironment of injured murine gut elicits a local pro-restitutive microbiota. Nat Microbiol 1: 15021.

Ammann P, Rizzoli R, Bonjour JP, Bourrin S, Meyer JM, Vassalli P, Garcia I. 1997. Transgenic mice expressing soluble tumor necrosis factor-receptor are protected against bone loss caused by estrogen deficiency. J Clin Invest 99: 1699-1703.

Anderson RC, Cookson AL, McNabb WC, Park Z, McCann MJ, Kelly WJ, Roy NC. 2010. Lactobacillus plantarum MB452 enhances the function of the intestinal barrier by increasing the expression levels of genes involved in tight junction formation. BMC Microbiol 10: 316. 
R. Pacifici

Ardita CS, Mercante JW, Kwon YM, Luo L, Crawford ME Powell DN, Jones RM, Neish AS. 2014. Epithelial adhesion mediated by pilin $\mathrm{SpaC}$ is required for Lactobacillus rhamnosus GG-induced cellular responses. Appl Environ Microbiol 80: 5068-5077.

Armstrong CM, Billimek AR, Allred KF, Sturino JM, Weeks BR, Allred CD. 2013. A novel shift in estrogen receptor expression occurs as estradiol suppresses inflammationassociated colon tumor formation. Endocr Relat Cancer 20: $515-525$.

Arpaia N, Campbell C, Fan X, Dikiy S, van der Veeken J, deRoos P, Liu H, Cross JR, Pfeffer K, Coffer PJ, et al. 2013. Metabolites produced by commensal bacteria promote peripheral regulatory T-cell generation. Nature 504: 451-455.

Asarat M, Apostolopoulos V, Vasiljevic T, Donkor O. 2015. Short-chain fatty acids produced by synbiotic mixtures in skim milk differentially regulate proliferation and cytokine production in peripheral blood mononuclear cells. Int J Food Sci Nutr 66: 755-765.

Basu R, Hatton RD, Weaver CT. 2013. The Th17 family: Flexibility follows function. Immunol Rev 252: 89-103.

Belkaid Y, Hand TW. 2014. Role of the microbiota in immunity and inflammation. Cell 157: 121-141.

Bernard-Poenaru O, Roux C, Blanque R, Gardner C, de Vemejoul MC, Cohen-Solal ME. 2001. Bone-resorbing cytokines from peripheral blood mononuclear cells after hormone replacement therapy: A longitudinal study. Osteoporos Int 12: 769-776.

Bilezikian JP, Morishima A, Bell J, Grumbach MM. 1998. Increased bone mass as a result of estrogen therapy in a man with aromatase deficiency. N Engl J Med 339: 599603.

Blanton LV, Charbonneau MR, Salih T, Barratt MJ, Venkatesh S, Ilkaveya O, Subramanian S, Manary MJ, Trehan I Jorgensen JM, et al. 2016. Gut bacteria that prevent growth impairments transmitted by microbiota from malnourished children. Science 351: aad3311.

Britton RA, Irwin R, Quach D, Schaefer L, Zhang J, Lee T, Parameswaran N, McCabe LR. 2014. Probiotic L. reuteri treatment prevents bone loss in a menopausal ovariectomized mouse model. J Cell Physiol 229: 1822-1830.

Bron PA, van Baarlen P, Kleerebezem M. 2012. Emerging molecular insights into the interaction between probiotics and the host intestinal mucosa. Nat Rev Microbiol 10: 66-78.

Burge R, Dawson-Hughes B, Solomon DH, Wong JB, King A, Tosteson A. 2007. Incidence and economic burden of osteoporosis-related fractures in the United States, 20052025. J Bone Miner Res 22: 465-475.

Cardinale BJ, Duffy JE, Gonzalez A, Hooper DU, Perrings C, Venail P, Narwani A, Mace GM, Tilman D, Wardle DA, et al. 2012. Biodiversity loss and its impact on humanity. Nature 486: 59-67.

Cenci S, Weitzmann MN, Roggia C, Namba N, Novack D, Woodring J, Pacifici R. 2000. Estrogen deficiency induces bone loss by enhancing T-cell production of TNF- $\alpha$. J Clin Invest 106: 1229-1237.

Cenci S, Toraldo G, Weitzmann MN, Roggia C, Gao Y, Qian WP, Sierra O, Pacifici R. 2003. Estrogen deficiency in duces bone loss by increasing $\mathrm{T}$ cell proliferation and lifespan through IFN- $\gamma$-induced class II transactivator. Proc Natl Acad Sci 100: 10405-10410.

Charatcharoenwitthaya N, Khosla S, Atkinson EJ, McCready LK, Riggs BL. 2007. Effect of blockade of tumor necrosis factor- $\alpha$ and interleukin- 1 action on bone resorption in early postmenopausal women. J Bone Miner Res 22: 724729.

Charbonneau MR, O’Donnell D, Blanton LV, Totten SM, Davis JC, Barratt MJ, Cheng J, Guruge J, Talcott M, Bain JR, et al. 2016. Sialylated milk oligosaccharides promote microbiota-dependent growth in models of infant undernutrition. Cell 164: 859-871.

Charles JF, Ermann J, Aliprantis AO. 2015. The intestinal microbiome and skeletal fitness: Connecting bugs and bones. Clin Immunol 159: 163-169.

Chen DY, Chen YM, Chen HH, Hsieh CW, Lin CC, Lan JL. 2011. Increasing levels of circulating Th17 cells and interleukin-17 in rheumatoid arthritis patients with an inadequate response to anti-TNF- $\alpha$ therapy. Arthritis Res Ther 13: R126.

Chiang SS, Pan TM. 2011. Antiosteoporotic effects of Lactobacillus-fermented soy skim milk on bone mineral density and the microstructure of femoral bone in ovariectomized mice. J Agric Food Chem 59: 7734-7742.

Cho I, Yamanishi S, Cox L, Methe BA, Zavadil J, Li K, Gao Z, Mahana D, Raju K, Teitler I, et al. 2012. Antibiotics in early life alter the murine colonic microbiome and adiposity. Nature 488: 621-626.

Chonan O, Matsumoto K, Watanuki M. 1995. Effect of galactooligosaccharides on calcium absorption and preventing bone loss in ovariectomized rats. Biosci Biotechnol Biochem 59: 236-239.

Cohen-Solal ME, Graulet AM, Denne MA, Gueris J, Baylink D, de Vernejoul MC. 1993. Peripheral monocyte culture supernatants of menopausal women can induce bone resorption: Involvement of cytokines. J Clin Endocrinol Metab 77: 1648-1653.

Collins FL, Irwin R, Bierhalter H, Schepper J, Britton RA, Parameswaran N, McCabe LR. 2016. Lactobacillus reuteri 6475 increases bone density in intact females only under an inflammatory setting. PLoS ONE 11: e0153180.

Cox LM, Yamanishi S, Sohn J, Alekseyenko AV, Leung JM, Cho I, Kim SG, Li H, Gao Z, Mahana D, et al. 2014. Altering the intestinal microbiota during a critical developmental window has lasting metabolic consequences. Cell 158: 705-721.

Cromwell GL. 2002. Why and how antibiotics are used in swine production. Anim Biotechnol 13: 7-27.

Cummings SR, Melton LJ. 2002. Epidemiology and outcomes of osteoporotic fractures. Lancet 359: 1761-1767.

D’Amelio P, Grimaldi A, Di Bella S, Brianza SZ, Cristofaro MA, Tamone C, Giribaldi G, Ulliers D, Pescarmona GP, Isaia G. 2008. Estrogen deficiency increases osteoclastogenesis up-regulating T cells activity: A key mechanism in osteoporosis. Bone 43: 92-100.

DeSelm CJ, Takahata Y, Warren J, Chappel JC, Khan T, Li X, Liu C, Choi Y, Kim YF, Zou W, et al. 2012. IL-17 mediates estrogen-deficient osteoporosis in an Actl-dependent manner. J Cell Biochem 113: 2895-2902.

DiGiulio DB, Callahan BJ, McMurdie PJ, Costello EK, Lyell DJ, Robaczewska A, Sun CL, Goltsman DS, Wong RJ, 
Bone Remodeling and the Microbiome

Shaw G, et al. 2015. Temporal and spatial variation of the human microbiota during pregnancy. Proc Natl Acad Sci 112: $11060-11065$.

Donohoe DR, Garge N, Zhang X, Sun W, O'Connell TM, Bunger MK, Bultman SJ. 2011. The microbiome and butyrate regulate energy metabolism and autophagy in the mammalian colon. Cell Metab 13: 517-526.

Eckburg PB, Bik EM, Bernstein CN, Purdom E, Dethlefsen L, Sargent M, Gill SR, Nelson KE, Relman DA. 2005. Diversity of the human intestinal microbial flora. Science 308: $1635-1638$

Eghbali-Fatourechi G, Khosla S, Sanyal A, Boyle WJ, Lacey DL, Riggs BL. 2003. Role of RANK ligand in mediating increased bone resorption in early postmenopausal women. J Clin Invest 111: 1221-1230.

Ericsson AC, Davis JW, Spollen W, Bivens N, Givan S, Hagan CE, McIntosh M, Franklin CL. 2015. Effects of vendor and genetic background on the composition of the fecal microbiota of inbred mice. PLoS ONE 10: e0116704.

Fasano A. 2012. Leaky gut and autoimmune diseases. Clin Rev Allergy Immunol 42: 71-78.

Filardo EJ, Quinn JA, Bland KI, Frackelton AR. 2000. Estrogen-induced activation of Erk-1 and Erk-2 requires the G protein-coupled receptor homolog, GPR30, and occurs via trans-activation of the epidermal growth factor receptor through release of HB-EGF. Mol Endocrinol 14: 16491660.

Fink HA, Ewing SK, Ensrud KE, Barrett-Connor E, Taylor BC, Cauley JA, Orwoll ES. 2006. Association of testosterone and estradiol deficiency with osteoporosis and rapid bone loss in older men. J Clin Endocrinol Metab 91: 3908-3915.

Finkelstein JS, Klibanski A, Neer RM, Greenspan SL, Rosenthal DI, Crowley WF Jr. 1987. Osteoporosis in men with idiopathic hypogonadotropic hypogonadism. Ann Intern Med 106: 354-361.

Finkelstein JS, Lee H, Leder BZ, Burnett-Bowie SA, Goldstein DW, Hahn CW, Hirsch SC, Linker A, Perros N, Servais AB, et al. 2016. Gonadal steroid-dependent effects on bone turnover and bone mineral density in men. J Clin Invest 126: $1114-1125$.

Flores R, Shi J, Fuhrman B, Xu X, Veenstra TD, Gail MH, Gajer P, Ravel J, Goedert JJ. 2012. Fecal microbial determinants of fecal and systemic estrogens and estrogen metabolites: A cross-sectional study. J Transl Med 10: 253.

Fuhrman BJ, Feigelson HS, Flores R, Gail MH, Xu X, Ravel J, Goedert JJ. 2014. Associations of the fecal microbiome with urinary estrogens and estrogen metabolites in postmenopausal women. J Clin Endocrinol Metab 99: 46324640.

Fujisaki J, Wu J, Carlson AL, Silberstein L, Putheti P, Larocca R, Gao W, Saito TI, Lo Celso C, Tsuyuzaki H, et al. 2011. In vivo imaging of $\mathrm{T}_{\text {reg }}$ cells providing immune privilege to the haematopoietic stem-cell niche. Nature 474: 216 219.

Furusawa Y, Obata Y, Fukuda S, Endo TA, Nakato G, Takahashi D, Nakanishi Y, Uetake C, Kato K, Kato T, et al. 2013. Commensal microbe-derived butyrate induces the differentiation of colonic regulatory T cells. Nature 504: 446-450.

Gao Y, Qian WP, Dark K, Toraldo G, Lin AS, Guldberg RE, Flavell RA, Weitzmann MN, Pacifici R. 2004. Estrogen prevents bone loss through transforming growth factor $\beta$ signaling in T cells. Proc Natl Acad Sci 101: 1661816623.

Gao Y, Grassi F, Ryan MR, Terauchi M, Page K, Yang X, Weitzmann MN, Pacifici R. 2007. IFN- $\gamma$ stimulates osteoclast formation and bone loss in vivo via antigen-driven $\mathrm{T}$ cell activation. J Clin Invest 117: 122-132.

Garcia-Vieyra MI, Del Real A, Lopez MG. 2014. Agave fructans: Their effect on mineral absorption and bone mineral content. J Med Food 17: 1247-1255.

Gevers D, Kugathasan S, Denson LA, Vazquez-Baeza Y, Van Treuren W, Ren B, Schwager E, Knights D, Song SJ, Yassour M, et al. 2014. The treatment-naive microbiome in new-onset Crohn's disease. Cell Host Microbe 15: 382 392.

Gibson GR, Probert HM, Loo JV, Rastall RA, Roberfroid MB. 2004. Dietary modulation of the human colonic microbiota: Updating the concept of prebiotics. Nutr Res Rev 17: 259-275.

Grassi F, Tell G, Robbie-Ryan M, Gao Y, Terauchi M, Yang X, Romanello M, Jones DP, Weitzmann MN, Pacifici R. 2007. Oxidative stress causes bone loss in estrogen-deficient mice through enhanced bone marrow dendritic cell activation. Proc Natl Acad Sci 104: 15087-15092.

Grice EA, Snitkin ES, Yockey LJ, Bermudez DM, Program NCS, Liechty KW, Segre JA. 2010. Longitudinal shift in diabetic wound microbiota correlates with prolonged skin defense response. Proc Natl Acad Sci 107: 1479914804.

Griffin IJ, Davila PM, Abrams SA. 2002. Non-digestible oligosaccharides and calcium absorption in girls with adequate calcium intakes. Br J Nutr 87: S187-S191.

Hernandez CJ, Guss JD, Luna M, Goldring SR. 2016. Links between the microbiome and bone. J Bone Miner Res 31: $1638-1646$.

Heyman M, Abed J, Lebreton C, Cerf-Bensussan N. 2012. Intestinal permeability in coeliac disease: Insight into mechanisms and relevance to pathogenesis. Gut 61: 1355-1364.

Hijazi Z, Molla AM, Al-Habashi H, Muawad WMRA, Molla AM, Sharma PN. 2004. Intestinal permeability is increased in bronchial asthma. Arch Dis Child 89: 227-229.

Human Microbiome Project Consortium. 2012. A framework for human microbiome research. Nature 486: 215 221.

Ismail AS, Hooper LV. 2005. Epithelial cells and their neighbors. IV: Bacterial contributions to intestinal epithelial barrier integrity. Am J Physiol Gastrointest Liver Physiol 289: G779-G784.

Ivanov II, Atarashi K, Manel N, Brodie EL, Shima T, Karaoz U, Wei D, Goldfarb KC, Santee CA, Lynch SV, et al. 2009. Induction of intestinal Th17 cells by segmented filamentous bacteria. Cell 139: 485-498.

Jha S, Wang Z, Laucis N, Bhattacharyya T. 2015. Trends in media reports, oral bisphosphonate prescriptions, and hip fractures 1996-2012: An ecological analysis. J Bone Miner Res 30: 2179-2187.

Johnell O, Kanis JA. 2006. An estimate of the worldwide prevalence and disability associated with osteoporotic fractures. Osteoporos Int 17: 1726-1733. 
R. Pacifici

Jones RM, Mercante JW, Neish AS. 2012. Reactive oxygen production induced by the gut microbiota: Pharmacotherapeutic implications. Curr Med Chem 19: 15191529.

Jones RM, Luo L, Ardita CS, Richardson AN, Kwon YM, Mercante JW, Alam A, Gates CL, Wu H, Swanson PA, et al. 2013. Symbiotic lactobacilli stimulate gut epithelial proliferation via Nox-mediated generation of reactive oxygen species. EMBO J 32: 3017-3028.

Jones RM, Desai C, Darby TM, Luo L, Wolfarth AA, Scharer CD, Ardita CS, Reedy AR, Keebaugh ES, Neish AS. 2015. Lactobacilli modulate epithelial cytoprotection through the Nrf2 pathway. Cell Rep 12: 1217-1225.

Jovanovic DV, Di Battista JA, Martel-Pelletier J, Jolicoeur FC, He Y, Zhang M, Mineau F, Pelletier JP. 1998. IL-17 stimulates the production and expression of proinflammatory cytokines, IL- $\beta$ and TNF- $\alpha$, by human macrophages. J Immunol 160: 3513-3521.

Karlsson FH, Tremaroli V, Nookaew I, Bergstrom G, Behre CJ, Fagerberg B, Nielsen J, Backhed F. 2013. Gut metagenome in European women with normal, impaired and diabetic glucose control. Nature 498: 99-103.

Kelchtermans H, Geboes L, Mitera T, Huskens D, Leclercq G, Matthys P. 2009. Activated $\mathrm{CD}^{+} \mathrm{CD} 25^{+}$regulatory T cells inhibit osteoclastogenesis and collagen-induced arthritis. Ann Rheum Dis 68: 744-750.

Khosla S, Pacifici R. 2013. Estrogen deficiency, postmenopausalosteoporosis, and age-related bone loss. In Osteoporosis (ed. Marcus R, Feldman D, Dempster DW, Luckey M, Cauley JA), Vol. 2, pp. 1113-1138. Elsevier, Amsterdam.

Khosla S, Shane E. 2016. A crisis in the treatment of osteoporosis. J Bone Miner Res 31: 1485-1487.

Kim YG, Lee CK, Nah SS, Mun SH, Yoo B, Moon HB. 2007. Human $\mathrm{CD} 4{ }^{+} \mathrm{CD} 25^{+}$regulatory $\mathrm{T}$ cells inhibit the differentiation of osteoclasts from peripheral blood mononuclear cells. Biochem Biophys Res Commun 357: $1046-$ 1052.

Kim SC, Kim DH, Mogun H, Eddings W, Polinski JM, Franklin JM, Solomon DH. 2016. Impact of the U.S. Food and Drug Administration's safety-related announcements on the use of bisphosphonates after hip fracture. J Bone Miner Res 31: 1536-1540.

Kimble RB, Bain S, Pacifici R. 1997. The functional block of TNF but not of IL-6 prevents bone loss in ovariectomized mice. J Bone Miner Res 12: 935-941.

Knip M, Siljander H. 2016. The role of the intestinal microbiota in type 1 diabetes mellitus. Nat Rev Endocrinol 12: $154-167$.

Komatsu N, Takayanagi H. 2012. Autoimmune arthritis: The interface between the immune system and joints. Advance Immunol 115: 45-71.

Kotake S, Udagawa N, Takahashi N, Matsuzaki K, Itoh K, Ishiyama S, Saito S, Inoue K, Kamatani N, Gillespie MT, et al. 1999. IL-17 in synovial fluids from patients with rheumatoid arthritis is a potent stimulator of osteoclastogenesis. J Clin Invest 103: 1345-1352.

Krum SA, Miranda-Carboni GA, Hauschka PV, Carroll JS, Lane TF, Freedman LP, Brown M. 2008. Estrogen protects bone by inducing Fas ligand in osteoblasts to regulate osteoclast survival. EMBO J 27: 535-545.
Krych L, Hansen CH, Hansen AK, van den Berg FW, Nielsen DS. 2013. Quantitatively different, yet qualitatively alike: A meta-analysis of the mouse core gut microbiome with a view towards the human gut microbiome. PLoS ONE 8: e62578.

Kurabayashi T, Fujimaki T, Yasuda M, Yamamoto Y, Tanaka K. 1993. Time-course of vertebral and femoral bone loss in rats administered gonadotrophin-releasing hormone agonist. J Endocrinol 138: 115-125.

Lam J, Takeshita S, Barker JE, Kanagawa O, Ross FP, Teitelbaum SL. 2000. TNF- $\alpha$ induces osteoclastogenesis by direct stimulation of macrophages exposed to permissive levels of RANK ligand. J Clin Invest 106: 1481-1488.

Lane DJ, Pace B, Olsen GJ, Stahl DA, Sogin ML, Pace NR. 1985. Rapid determination of $16 \mathrm{~S}$ ribosomal RNA sequences for phylogenetic analyses. Proc Natl Acad Sci 82: 6955-6959.

Laukens D, Brinkman BM, Raes J, De Vos M, Vandenabeele P. 2016. Heterogeneity of the gut microbiome in mice: Guidelines for optimizing experimental design. FEMS Microbiol Rev 40: 117-132.

Lee YK, Menezes JS, Umesaki Y, Mazmanian SK. 2011. Proinflammatory T-cell responses to gut microbiota promote experimental autoimmune encephalomyelitis. Proc Natl Acad Sci 108: 4615-4622.

Legette LL, Lee W, Martin BR, Story JA, Campbell JK, Weaver CM. 2012. Prebiotics enhance magnesium absorption and inulin-based fibers exert chronic effects on calcium utilization in a postmenopausal rodent model. J Food Sci 77: $\mathrm{H} 88-\mathrm{H} 94$.

Lelu K, Laffont S, Delpy L, Paulet PE, Perinat T, Tschanz SA, Pelletier L, Engelhardt B, Guery JC. 2011. Estrogen receptor $\alpha$ signaling in T lymphocytes is required for estradiolmediated inhibition of Th1 and Th17 cell differentiation and protection against experimental autoimmune encephalomyelitis. J Immunol 187: 2386-2393.

Lewis JR, Hassan SK, Wenn RT, Moran CG. 2006. Mortality and serum urea and electrolytes on admission for hip fracture patients. Injury 37: 698-704.

Li JY, Tawfeek H, Bedi B, Yang X, Adams J, Gao KY, Zayzafoon M, Weitzmann MN, Pacifici R. 2011. Ovariectomy disregulates osteoblast and osteoclast formation through the T-cell receptor CD40 ligand. Proc Natl Acad Sci 108: $768-773$.

Li JY, D’Amelio P, Robinson J, Walker LD, Vaccaro C, Luo T, Tyagi AM, Yu M, Reott M, Sassi F, et al. 2015. IL-17A is increased in humans with primary hyperparathyroidism and mediates PTH-induced bone loss in mice. Cell Metab 22: 799-810.

Li JY, Chassaing B, Tyagi AM, Vaccaro C, Luo T, Adams J, Darby TM, Weitzmann MN, Mulle JG, Gewirtz AT, et al. 2016. Sex steroid deficiency-associated bone loss is microbiota dependent and prevented by probiotics. J Clin Invest. 126: 2049-2063.

Ma TY, Anderson JM. 2006. Tight junctions and the intestinal barrier. In Physiology of the gastrointestinal tract, 4th ed. (ed. Barrett KE, Ghishan FK, Merchant JL, Said HM, Wood JD), Vols. 1 \& 2, pp. 1559-1594. Elsevier, Amsterdam.

Madsen K, Cornish A, Soper P, McKaigney C, Jijon H, Yachimec C, Doyle J, Jewell L, De Simone C. 2001. Probiotic 
Bone Remodeling and the Microbiome

bacteria enhance murine and human intestinal epithelial barrier function. Gastroenterology 121: 580-591.

Mazmanian SK, Kasper DL. 2006. The love-hate relationship between bacterial polysaccharides and the host immune system. Nat Rev 6: 849-858.

McCabe LR, Irwin R, Schaefer L, Britton RA. 2013. Probiotic use decreases intestinal inflammation and increases bone density in healthy male but not female mice. J Cell Physiol 228: 1793-1798.

McCabe L, Britton RA, Parameswaran N. 2015. Prebiotic and probiotic regulation of bone health: Role of the intestine and its microbiome. Curr Osteoporos Rep 13:363371.

McDole JR, Wheeler LW, McDonald KG, Wang B, Konjufca V, Knoop KA, Newberry RD, Miller MJ. 2012. Goblet cells deliver luminal antigen to $\mathrm{CD} 103^{+}$dendritic cells in the small intestine. Nature 483: 345-349.

Miossec P, Korn T, Kuchroo VK. 2009. Interleukin-17 and type 17 helper T cells. N Engl J Med 361: 888-898.

Molnar I, Bohaty I, Somogyine-Vari E. 2014a. IL-17A-mediated sRANK ligand elevation involved in postmenopausal osteoporosis. Osteoporos Int 25: 783-786.

Molnar I, Bohaty I, Somogyine-Vari E. 2014b. High prevalence of increased interleukin-17A serum levels in postmenopausal estrogen deficiency. Menopause 21: 749 752.

Momozawa Y, Deffontaine V, Louis E, Medrano JF. 2011. Characterization of bacteria in biopsies of colon and stools by high throughput sequencing of the V2 region of bacterial 16S rRNA gene in human. PLoS ONE 6: e16952.

Mutus R, Kocabagli N, Alp M, Acar N, Eren M, Gezen SS. 2006. The effect of dietary probiotic supplementation on tibial bone characteristics and strength in broilers. Poult Sci 85: 1621-1625.

Nakamura T, Imai Y, Matsumoto T, Sato S, Takeuchi K, Igarashi K, Harada Y, Azuma Y, Krust A, Yamamoto Y, et al. 2007. Estrogen prevents bone loss via estrogen receptor $\alpha$ and induction of Fas ligand in osteoclasts. Cell 130: 811-823.

Narva M, Collin M, Lamberg-Allardt C, Karkkainen M, Poussa T, Vapaatalo H, Korpela R. 2004. Effects of longterm intervention with Lactobacillus helveticus-fermented milk on bone mineral density and bone mineral content in growing rats. Ann Nutr Metab 48: 228-234.

NIH HMP Working Group; Peterson J, Garges S, Giovanni M, McInnes P, Wang L, Schloss JA, Bonazzi V, McEwen JE, Wetterstrand KA, et al. 2009. The NIH Human Microbiome Project. Genome Res 19: 2317-2323.

Nobel YR, Cox LM, Kirigin FF, Bokulich NA, Yamanishi S, Teitler I, Chung J, Sohn J, Barber CM, Goldfarb DS, et al. 2015. Metabolic and metagenomic outcomes from earlylife pulsed antibiotic treatment. Nat Commun 6: 7486 .

Noverr MC, Falkowski NR, McDonald RA, McKenzie AN, Huffnagle GB. 2005. Development of allergic airway disease in mice following antibiotic therapy and fungal microbiota increase: Role of host genetics, antigen, and interleukin-13. Infect Immun 73: 30-38.

O’Boyle CJ, MacFie J, Mitchell CJ, Johnstone D, Sagar PM, Sedman PC. 1998. Microbiology of bacterial translocation in humans. Gut 42: 29-35.
Ohlsson C, Engdahl C, Fak F, Andersson A, Windahl SH, Farman HH, Moverare-Skrtic S, Islander U, Sjogren K. 2014. Probiotics protect mice from ovariectomy-induced cortical bone loss. PLoS ONE 9: e92368.

Pacifici R. 2012. Role of T cells in ovariectomy induced bone loss-revisited. J Bone Miner Res 27: 231-239.

Pacifici R, Rifas L, McCracken R, Vered I, McMurtry C, Avioli LV, Peck WA. 1989. Ovarian steroid treatment blocks a postmenopausal increase in blood monocyte interleukin 1 release. Proc Natl Acad Sci 86: 2398-2402.

Pacifici R, Brown C, Puscheck E, Friedrich E, Slatopolsky E, Maggio D, McCracken R, Avioli LV. 1991. Effect of surgical menopause and estrogen replacement on cytokine release from human blood mononuclear cells. Proc Natl Acad Sci 88: 5134-5138.

Penders J, Stobberingh EE, Savelkoul PH, Wolffs PF. 2013. The human microbiome as a reservoir of antimicrobial resistance. Front Microbiol 4: 87.

Preidis GA, Saulnier DM, Blutt SE, Mistretta TA, Riehle KP, Major AM, Venable SF, Finegold MJ, Petrosino JF, Conner ME, et al. 2012. Probiotics stimulate enterocyte migration and microbial diversity in the neonatal mouse intestine. FASEB J 26: 1960-1969.

Pull SL, Doherty JM, Mills JC, Gordon JI, Stappenbeck TS. 2005. Activated macrophages are an adaptive element of the colonic epithelial progenitor niche necessary for regenerative responses to injury. Proc Natl Acad Sci 102: 99-104.

Qin J, Li R, Raes J, Arumugam M, Burgdorf KS, Manichanh C, Nielsen T, Pons N, Levenez F, Yamada T, et al. 2010. A human gut microbial gene catalogue established by metagenomic sequencing. Nature 464: 59-65.

Qin B, Dong L, Guo X, Jiang J, He Y, Wang X, Li L, Zhao J. 2014. Expression of $G$ protein-coupled estrogen receptor in irritable bowel syndrome and its clinical significance. Int J Clin Exp Pathol 7: 2238-2246.

Raehtz S, Fedorko A, McCabe L. 2014. Estrogen deficiency induced intestinal inflammation and permeability is linked with osteoporosis (488.8). FASEB J 28(Suppl.).

Ravel J, Gajer P, Abdo Z, Schneider GM, Koenig SS, McCulle SL, Karlebach S, Gorle R, Russell J, Tacket CO, et al. 2011. Vaginal microbiome of reproductive-age women. Proc Natl Acad Sci 108: 4680-4687.

Riggs BL, Melton LJ III. 1983. Evidence for two distinct syndromes of involutional osteoporosis. Am J Med 75: 899-901.

Riggs BL, Melton LJ III. 1986. Involutional osteoporosis. N Engl J Med 314: 1676-1686.

Roberfroid MB, Cumps J, Devogelaer JP. 2002. Dietary chicory inulin increases whole-body bone mineral density in growing male rats. J Nutr 132: 3599-3602.

Roggia C, Gao Y, Cenci S, Weitzmann MN, Toraldo G, Isaia G, Pacifici R. 2001. Up-regulation of TNF-producing T cells in the bone marrow: A key mechanism by which estrogen deficiency induces bone loss in vivo. Proc Natl Acad Sci 98: 13960-13965.

Salminen S, Ouwehand A, Benno Y, Lee YK. 1999. Probiotics: How should they be defined? Trends Food Sci Technol 10: $107-110$.

Sato K, Suematsu A, Okamoto K, Yamaguchi A, Morishita Y, Kadono Y, Tanaka S, Kodama T, Akira S, Iwakura Y, et al. 
R. Pacifici

2006. Th17 functions as an osteoclastogenic helper T cell subset that links $\mathrm{T}$ cell activation and bone destruction. $J$ Exp Med 203: 2673-2682.

Scher JU, Ubeda C, Equinda M, Khanin R, Buischi Y, Viale A, Lipuma L, Attur M, Pillinger MH, Weissmann G, et al. 2012. Periodontal disease and the oral microbiota in newonset rheumatoid arthritis. Arthritis Rheum 64: 30833094.

Scher JU, Ubeda C, Artacho A, Attur M, Isaac S, Reddy SM, Marmon S, Neimann A, Brusca S, Patel T, et al. 2015. Decreased bacterial diversity characterizes the altered gut microbiota in patients with psoriatic arthritis, resembling dysbiosis in inflammatory bowel disease. Arthritis Rheumatol 67: 128-139.

Scholz-Ahrens KE, Ade P, Marten B, Weber P, Timm W, Acil Y, Gluer CC, Schrezenmeir J. 2007. Prebiotics, probiotics, and synbiotics affect mineral absorption, bone mineral content, and bone structure. J Nutr 137: 838s-846s.

Schwarzer M, Makki K, Storelli G, Machuca-Gayet I, Srutkova D, Hermanova P, Martino ME, Balmand S, Hudcovic T, Heddi A, et al. 2016. Lactobacillus plantarum strain maintains growth of infant mice during chronic undernutrition. Science 351: 854-857.

Seth A, Yan F, Polk DB, Rao RK. 2008. Probiotics ameliorate the hydrogen peroxide-induced epithelial barrier disruption by a PKC- and MAP kinase-dependent mechanism. Am J Physiol 294: G1060-G1069.

Shendure J, Ji H. 2008. Next-generation DNA sequencing. Nat Biotechnol 26: 1135-1145.

Sjogren K, Engdahl C, Henning P, Lerner UH, Tremaroli V, Lagerquist MK, Backhed F, Ohlsson C. 2012. The gut microbiota regulates bone mass in mice. J Bone Miner Res 27: 1357-1367.

Slevin MM, Allsopp PJ, Magee PJ, Bonham MP, Naughton VR, Strain JJ, Duffy ME, Wallace JM, Mc Sorley EM 2014. Supplementation with calcium and short-chain fructo-oligosaccharides affects markers of bone turnover but not bone mineral density in postmenopausal women. J Nutr 144: 297-304.

Smith PM, Howitt MR, Panikov N, Michaud M, Gallini CA Bohlooly YM, Glickman JN, Garrett WS. 2013. The microbial metabolites, short-chain fatty acids, regulate colonic $\mathrm{T}_{\text {reg }}$ cell homeostasis. Science 341: 569-573.

Sobel V, Schwartz B, Zhu YS, Cordero JJ, Imperato-McGinley J. 2006. Bone mineral density in the complete androgen insensitivity and $5 \alpha$-reductase- 2 deficiency syndromes. J Clin Endocrinol Metab 91: 3017-3023.

Sommer F, Backhed F. 2013. The gut microbiota-Masters of host development and physiology. Nat Rev Microbiol 11: 227-238.

Stappenbeck TS, Virgin HW. 2016. Accounting for reciprocal host-microbiome interactions in experimental science. Nature 534: 191-199.

Stappenbeck TS, Hooper LV, Gordon JI. 2002. Developmental regulation of intestinal angiogenesis by indigenous microbes via Paneth cells. Proc Natl Acad Sci 99: 15451-15455.

Sugita S, Kawazoe Y, Imai A, Yamada Y, Horie S, Mochizuki M. 2012. Inhibition of Th17 differentiation by anti-TNF$\alpha$ therapy in uveitis patients with Behcet's disease. Arthritis Res Ther 14: R99.
Sun L, Peng Y, Sharrow AC, Iqbal J, Zhang Z, Papachristou DJ, Zaidi S, Zhu LL, Yaroslavskiy BB, Zhou H, et al. 2006. FSH directly regulates bone mass. Cell 125: 247-260.

Surana NK, Kasper DL. 2014. Deciphering the tête-à-tête between the microbiota and the immune system. J Clin Invest 124: 4197-4203.

Surh CD, Sprent J. 2008. Homeostasis of naive and memory T cells. Immunity 29: 848-862.

Takahara S, Morohashi T, Sano T, Ohta A, Yamada S, Sasa R. 2000. Fructooligosaccharide consumption enhances femoral bone volume and mineral concentrations in rats. J Nutr 130: 1792-1795.

Taxel P, Kaneko H, Lee SK, Aguila HL, Raisz LG, Lorenzo JA. 2008. Estradiol rapidly inhibits osteoclastogenesis and RANKL expression in bone marrow cultures in postmenopausal women: A pilot study. Osteoporos Int 19: $193-$ 199.

Teixeira TFS, Collado MC, Ferreira CLLF, Bressan J, Peluzio MDG. 2012. Potential mechanisms for the emerging link between obesity and increased intestinal permeability. Nutr Res 32: 637-647.

Tomofuji T, Ekuni D, Azuma T, Irie K, Endo Y, Yamamoto T, Ishikado A, Sato T, Harada K, Suido H, et al. 2012. Supplementation of broccoli or Bifidobacterium longum-fermented broccoli suppresses serum lipid peroxidation and osteoclast differentiation on alveolar bone surface in rats fed a high-cholesterol diet. Nutr Res 32: 301-307.

Tremaroli V, Backhed F. 2012. Functional interactions between the gut microbiota and host metabolism. Nature 489: $242-249$.

Turnbaugh PJ, Ley RE, Hamady M, Fraser-Liggett CM, Knight R, Gordon JI. 2007. The Human Microbiome Project. Nature 449: 804-810.

Turnbaugh PJ, Hamady M, Yatsunenko T, Cantarel BL, Duncan A, Ley RE, Sogin ML, Jones WJ, Roe BA, Affourtit JP, et al. 2009. A core gut microbiome in obese and lean twins. Nature 457: 480-484.

Tyagi AM, Srivastava K, Mansoori MN, Trivedi R, Chattopadhyay N, Singh D. 2012a. Estrogen deficiency induces the differentiation of IL-17 secreting Th17 cells: A new candidate in the pathogenesis of osteoporosis. PLOS ONE 7: e44552.

Tyagi AM, Srivastava K, Kureel J, Kumar A, Raghuvanshi A, Yadav D, Maurya R, Goel A, Singh D. 2012b. Premature T cell senescence in ovx mice is inhibited by repletion of estrogen and medicarpin: A possible mechanism for alleviating bone loss. Osteoporos Int 23: 1151-1161.

Tyagi AM, Mansoori MN, Srivastava K, Khan MP, Kureel J, Dixit M, Shukla P, Trivedi R, Chattopadhyay N, Singh D. 2014. Enhanced immunoprotective effects by anti-IL-17 antibody translates to improved skeletal parameters under estrogen deficiency compared with anti-RANKL and anti-TNF- $\alpha$ antibodies. J Bone Miner Res 29: 1981-1992.

Ulluwishewa D, Anderson RC, McNabb WC, Moughan PJ, Wells JM, Roy NC. 2011. Regulation of tight junction permeability by intestinal bacteria and dietary components. J Nutr 141: 769-776.

van den Heuvel EG, Schoterman MH, Muijs T. 2000. Transgalactooligosaccharides stimulate calcium absorption in postmenopausal women. J Nutr 130: 2938-2942. 
Bone Remodeling and the Microbiome

Veldhoen M, Hocking RJ, Atkins CJ, Locksley RM, Stockinger B. 2006. TGF $\beta$ in the context of an inflammatory cytokine milieu supports de novo differentiation of IL17-producing T cells. Immunity 24: 179-189.

Venken K, De Gendt K, Boonen S, Ophoff J, Bouillon R, Swinnen JV, Verhoeven G, Vanderschueren D. 2006. Relative impact of androgen and estrogen receptor activation in the effects of androgens on trabecular and cortical bone in growing male mice: A study in the androgen receptor knockout mouse model. J Bone Miner Res 21: 576-585.

Wada-Hiraike $\mathrm{O}$, Imamov $\mathrm{O}$, Hiraike $\mathrm{H}$, Hultenby $\mathrm{K}$, Schwend T, Omoto Y, Warner M, Gustafsson JA. 2006 Role of estrogen receptor $\beta$ in colonic epithelium. Proc Natl Acad Sci 103: 2959-2964.

Wade W. 2002. Unculturable bacteria-The uncharacterized organisms that cause oral infections. J R Soc Med 95: $81-83$.

Waisman A. 2011. T helper cell populations: As flexible as the skin? Eur J Immunol 41: 2539-2543.

Wang Y, Yano T, Kikuchi A, Yano N, Matsumi H, Ando K, Kasai Y, Watanabe M, Okagaki R, Osuga Y, et al. 2000. Comparison of the effects of add-back therapy with various natural oestrogens on bone metabolism in rats administered a long-acting gonadotrophin-releasing hormone agonist. J Endocrinol 165: 467-473.

Wang Y, Zhang J, Yi XJ, Yu FSX. 2004. Activation of ERK1/2 MAP kinase pathway induces tight junction disruption in human corneal epithelial cells. Exp Eye Res 78: 125-136.

Wang J, Qi J, Zhao H, He S, Zhang Y, Wei S, Zhao F. 2013. Metagenomic sequencing reveals microbiota and its functional potential associated with periodontal disease. Sci Rep 3: 1843.

Weaver CM. 2015. Diet, gut microbiome, and bone health. Curr Osteoporos Rep 13: 125-130.

Weaver CM, Martin BR, Story JA, Hutchinson I, Sanders L. 2010. Novel fibers increase bone calcium content and strength beyond efficiency of large intestine fermentation. J Agric Food Chem 58: 8952-8957.

Weitzmann MN, Pacifici R. 2006. Estrogen deficiency and bone loss: An inflammatory tale. JClin Invest 116: $1186-$ 1194.

Wentworth CC, Jones RM, Kwon YM, Nusrat A, Neish AS 2010. Commensal-epithelial signaling mediated via formyl peptide receptors. Am J Pathol 177: 2782-2790.

Wentworth CC, Alam A, Jones RM, Nusrat A, Neish AS. 2011a. Enteric commensal bacteria induce extracellular signal-regulated kinase pathway signaling via formyl peptide receptor-dependent redox modulation of dual specific phosphatase 3. J Biol Chem 286: 38448-38455.

Wentworth CC, Alam A, Jones RM, Nusrat A, Neish AS. 2011b. Enteric commensal bacteria induce ERK pathway signaling via formyl peptide receptor (FPR)-dependent redox modulation of dual specific phosphatase 3 (DUSP3). J Biol Chem 286: 38448-38455.
Williams S, Wakisaka A, Zeng QQ, Barnes J, Martin G, Wechter WJ, Liang CT. 1996. Minocycline prevents the decrease in bone mineral density and trabecular bone in ovariectomized aged rats. Bone 19: 637-644.

Wu HJ, Ivanov II, Darce J, Hattori K, Shima T, Umesaki Y, Littman DR, Benoist C, Mathis D. 2010. Gut-residing segmented filamentous bacteria drive autoimmune arthritis via T helper 17 cells. Immunity 32: 815-827.

Xiong J, Onal M, Jilka RL, Weinstein RS, Manolagas SC, O’Brien CA. 2011. Matrix-embedded cells control osteoclast formation. Nat Med 17: 1235-1241.

Yamaza T, Miura Y, Bi Y, Liu Y, Akiyama K, Sonoyama W, Patel V, Gutkind S, Young M, Gronthos S, et al. 2008. Pharmacologic stem cell based intervention as a new approach to osteoporosis treatment in rodents. PLoS ONE 3: e2615.

Yan F, Polk DB. 2011. Probiotics and immune health. Curr Opin Gastroenterol 27: 496-501.

Yan J, Herzog JW, Tsang K, Brennan CA, Bower MA, Garrett WS, Sartor BR, Aliprantis AO, Charles JF. 2016. Gut microbiota induce IGF-1 and promote bone formation and growth. Proc Natl Acad Sci 113: E7554-E7563.

Yu QH, Yang Q. 2009. Diversity of tight junctions (TJs) between gastrointestinal epithelial cells and their function in maintaining the mucosal barrier. Cell Biol Int 33: $78-82$.

Zafar TA, Weaver CM, Zhao Y, Martin BR, Wastney ME. 2004. Nondigestible oligosaccharides increase calcium absorption and suppress bone resorption in ovariectomized rats. J Nutr 134: 399-402.

Zaidi M. 2007. Skeletal remodeling in health and disease. Nat Med 13: 791-801.

Zaiss MM, Axmann R, Zwerina J, Polzer K, Guckel E, Skapenko A, Schulze-Koops H, Horwood N, Cope A, Schett G. 2007. $T_{\text {reg }}$ cells suppress osteoclast formation: A new link between the immune system and bone. Arthritis Rheum 56: 4104-4112.

Zeissig S, Burgel N, Gunzel D, Richter J, Mankertz J, Wahnschaffe U, Kroesen AJ, Zeitz M, Fromm M, Schulzke JD. 2007. Changes in expression and distribution of claudin 2, 5 and 8 lead to discontinuous tight junctions and barrier dysfunction in active Crohn's disease. Gut 56: 61-72.

Zeng H, Chi H. 2015. Metabolic control of regulatory T cell development and function. Trends Immunol 36: 3-12.

Zhang J, Fu Q, Ren Z, Wang Y, Wang C, Shen T, Wang G, Wu L. 2015. Changes of serum cytokines-related Th1/Th2/ Th17 concentration in patients with postmenopausal osteoporosis. Gynecol Endocrinol 31: 183-190.

Zhu Q, Gao R, Wu W, Qin H. 2013. The role of gut microbiota in the pathogenesis of colorectal cancer. Tumour Biol 34: 1285-1300. 


\section{$\$ \mathrm{CSH} \&$ Cold Spring Harbor

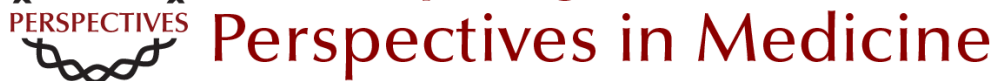

\section{Bone Remodeling and the Microbiome}

Roberto Pacifici

Cold Spring Harb Perspect Med 2018; doi: 10.1101/cshperspect.a031203 originally published online August 28, 2017

Subject Collection Bone: A Regulator of Physiology

\section{Mechanism of Bone Mineralization} Monzur Murshed

Neural Regulation of Bone and Bone Marrow Maria Maryanovich, Shoichiro Takeishi and Paul S. Frenette

Regulation of Bone Remodeling by Parathyroid Hormone Marc N. Wein and Henry M. Kronenberg

The Bone Marrow Microenvironment in Health and Myeloid Malignancy

Marta Galán-Díez, Álvaro Cuesta-Domínguez and Stavroula Kousteni

The Biology of Bone Metastasis

Mark Esposito, Theresa Guise and Yibin Kang

Bone Remodeling and the Microbiome Roberto Pacifici

\section{Osteoimmunology}

Kazuo Okamoto and Hiroshi Takayanagi

Multiple Myeloma and Bone: The Fatal Interaction Silvia Marino and G. David Roodman

Biology of Bone: The Vasculature of the Skeletal System

Emma C. Watson and Ralf H. Adams

Regulation of Energy Metabolism by

Bone-Derived Hormones

Paula Mera, Mathieu Ferron and Ioanna Mosialou

\section{Biology of Fibroblast Growth Factor 23: From \\ Physiology to Pathology \\ Marie Courbebaisse and Beate Lanske}

Regulation of Bone Metabolism by Sex Steroids Sundeep Khosla and David G. Monroe

For additional articles in this collection, see http://perspectivesinmedicine.cshlp.org/cgi/collection/ 